\title{
The Tolerable Cost of European Union Regulation: Leaving the EU and the Market for Politically Convenient Facts
}

\author{
GARY FOOKS* AND TOM MILLS** \\ *Aston University, School for Languages and Social Sciences, Birmingham B4 7ET, United \\ Kingdom \\ email: g.fooks@aston.ac.uk \\ **Aston University, School for Languages and Social Sciences, Birmingham B4 7ET, United \\ Kingdom \\ email: t.mills@aston.ac.uk
}

\begin{abstract}
European Union (EU) law-making has played a key role in promoting social equity in the UK through safer working conditions, enhanced rights for workers, and by reducing environmental pollution. Concerns over its effect on business competitiveness have long been a major driver of Euroscepticism, underpinning criticism of the EU by influential opinion formers within British conservatism. The Leave Campaign argued that EU laws damage the UK economy by imposing unnecessary costs on British business, claiming that EU regulations cost the UK economy $\mathfrak{E}_{33.3}$ billion per year. This paper examines the reliability of, and assumptions that underpin, aggregated estimates of the costs and benefits of EU-derived regulation, and considers how the economisation of public policy influences understanding of the social value of regulation. It brings together the findings of studies that have evaluated the accuracy of the estimated costs and benefits in formal impact assessments and analyses impact assessments of EU-derived policy instruments aimed at regulating working conditions. Our findings suggest that aggregated estimates represent poor guides to understanding the social costs and benefits of social regulation and highlight the value of discarding impact assessment estimates of costs and benefits in the context of efforts to shape social policy post-Brexit.
\end{abstract}

\section{Introduction}

Economists typically make a distinction between economic regulation, which is concerned with prices and entry controls, and social regulation, which governs other aspects of business activity and plays an important role in protecting the environment, safeguarding the rights and welfare of workers and consumers, and generally limiting the ability of companies to externalise costs onto governments and publics (Breyer, 1998). Incomplete or ineffective regulation can have farreaching effects on social equity and government expenditure. One cost-of-illness study on occupational asthma, for instance, estimated that individuals (49 per cent) and the state ( 48 per cent) shouldered 97 per cent of the burden, with just 
3 per cent borne by employers (Ayres et al., 2011). Strong, well-designed regulation, by contrast, can save lives. To take just one example, in the early 200os a DEFRAcommissioned study projected that air quality policies introduced between 1990 and 2001 affecting transport and electricity generation would reduce premature deaths by 6,857 , and save between 81,601 to 244,803 life years, in 2010 alone (Watkiss et al., 2004).

Despite representing an important protective buffer between unchecked economic activity and public well-being, claims that social regulation (hereafter regulation) negatively affects competitiveness, firm performance, output, and employment have come to dominate the public conversation on regulatory policy in the UK. Focusing initially on domestic regulation, these claims have progressively coalesced around European-Union-derived regulation, reflecting successive amendments to the Treaty of Rome, which have radically expanded European Union (EU) influence in UK policymaking (Miller, 2010, 2015). The EU's partial annexation of UK policy-making, and its alleged effects on business competitiveness, continued to drive British conservatism's antagonism towards the European project throughout the 2000s (Cash and Jamieson, 2004; Congdon, 2014; Economic Competitiveness Policy Group, 2007; Heath, 2016; Milne, 2004), and represented a key plank of Vote Leave's case for leaving the EU (Treasury Committee, 2016) despite the European Commission's best efforts to bring policymaking more closely into line with business interests (Smith et al., 2014).

Anti-regulatory sentiment derived support from both survey findings of business actors (Baldock and Blundel, 2014; National Audit Office and Department for Business Innovation and Skills, 2014), and thematic reports (Federation of Small Businesses, 2011) and lobbying (Federation of Small Businesses, 2013) by UK business associations. On the face of it, these appeared to confirm studies highlighting the negative impact of regulation on firm growth, and its disproportionate effects on small- and medium-sized enterprises, which are widely considered to be less able than larger firms to absorb the costs associated with regulation (Lancaster et al., 2003). On closer inspection though, the true picture is likely to be more complex. In-depth analyses of business survey data, for example, indicate that reported business perceptions of regulatory effects may exaggerate real business burdens as a result of business actors' misunderstandings of the actual costs and requirements of regulation, idiosyncrasies in survey design, ${ }^{1}$ and the inability of some respondents to think beyond immediate compliance costs and recognise longer term savings and business opportunities created by regulation (Allinson et al., 2006; Kitching, 2006; Kitching et al., 2015). In the event though, these epistemological and methodological nuances did little to alter the convictions of those on either side of the debate, which was dominated by the political fetish for large, eye-catching numbers. In evidence to the Treasury Committee inquiry into the costs of EU membership, for example, Vote Leave Campaign Director, Dominic Cummings, drew on estimates produced by the 
think tank, Open Europe (OE), to claim that EU regulations cost the UK economy $\mathfrak{E}_{33.3}$ billion per annum (Cummings, 2016). Cummings' use of OE's study did not entirely escape Parliamentary ire. However, the Treasury Committee only performed a cursory analysis of the underlying basis of OE's estimates of costs and benefits and whether they could serve as a reasonable guide to the societal impacts of EU-derived regulation (Treasury Committee, 2016).

This failure to systematically scrutinise OE's data is typical of how aggregated estimates of the social costs and benefits of regulation are processed in the public domain. OE had arrived at its estimates by summating figures contained in impact assessments by UK government departments of the '100 most burdensome' EUderived regulations (Swidlicki, 2015). The methodology behind OE's calculation was not outlined in the briefing publicising its findings (Swidlicki, 2015), but appears to follow the approach of earlier OE studies estimating the costs of EU regulations between 1998 and 2009 (Gaskell and Persson, 2010; Persson et al., 2009). These included administrative costs (costs attendant on producing information or complying with administrative functions, such as record-keeping or invoicing, required by regulation) and policy costs (costs incurred through meeting the aims of regulations) (Gaskell and Persson, 2010), but excluded items such as government expenditure and the 'knock-on effects on the wider economy' (Gaskell and Persson, 2010; Persson et al., 2009). OE's methodology broadly replicates the approach taken by business associations (Ambler et al., 2010) and other think tanks (Milne, 2004) in similar analyses which, over time, have subtly set the assumptions of debates on EU regulation: a consequence of being taken at face value in news commentary and reports (Holehouse, 2015), cited uncritically in formal policy analyses (Anon, HM Government, 2013, 2016), and used as the basis of calculations of the costs of EU membership by academics, business associations, political parties, and professional research consultants (Confederation of British Industry, 2016b; Congdon, 2016; Minford et al., 2005; PWC, 2016). However, the question of how far aggregated estimates of regulatory costs and benefits can be reasonably relied on, or whether focusing on business administrative and policy costs represents the most useful way of evaluating the social value of regulation, remains. This paper examines these questions, focusing on OE's analysis, which represents the most widely cited, and arguably most influential, estimate of the impact of EU regulation by the Leave Campaign (House of Commons Treasury Committee, 2016). Specifically, we review published studies examining the accuracy of cost-benefit projections in impact assessments, and explore three key issues relevant to the accuracy and representation of estimates in a sample of labour-related impact assessments in OE's analysis: uncertainties and assumptions in cost estimates; the explanatory value of OE's focus on administrative and policy costs; under-reporting of business and non-business benefits. We conclude with some brief observations about what aggregated cost-benefit estimates of EU-derived regulations can tell 
us about the economisation of public policymaking and the political economy of policy-relevant knowledge in the UK.

\section{Methods}

We undertook two types of analysis. First, to explore the general reliability, and potential biases, of cost projections in impact assessments, we conducted a deskbased review of studies comparing ex ante (before the event) estimates in impact assessments with independently conducted ex post (realised) evaluations. The database Web of Knowledge was initially searched for studies evaluating the accuracy of impact assessment cost estimates using a combination of search strings. Identical search strings were used in the internet search engine Google to identify grey literature. Additional studies were then identified by searching for studies (using Google Scholar) citing those identified through these initial searches. All searches were conducted between November and December 2016. Articles published prior to 2000, not written in English, and reproducing results from earlier dated studies in the sample were excluded from the analysis. In total, we identified 14 studies that met the inclusion criteria (see Table 1 in the supplementary materials).

Second, we examined a sample of final impact assessments of labourrelated regulations in OE's analysis $(n=10)$ (Tables 2 and 3 in the supplementary materials) to explore: the incidence and range of information uncertainties and assumptions therein (to illustrate their underlying value as a source of data for assessing administrative and policy costs of regulation); their reliance on business data (a potential source of overestimated costs); the estimated net cost of policy proposals in OE's sample (which provides a more comprehensive assessment of the costs of EU-derived regulations to business and their likely effects on aggregate economy-wide output, growth, and employment); the degree to which they report and monetise benefits (in order to explore patterns of under reporting/quantification of business and non-business benefits of EU-derived regulation in UK impact assessments). Labour-related regulations in OE's analysis $(n=18)$ were identified by reviewing OE's table of the 100 costliest EU-derived regulations in force in the UK (Swidlicki, 2015). Final impact assessments for these regulations were downloaded from the UK Government website between October and December 2016. We took a part purposive, part random approach to sampling: selecting all regulations with final impact assessments containing an estimate of the equivalent net annual cost to business (see further below) $(n=3)$, and taking a random sample of half of the remainder $(n=7)$. The Regulations represented the $5^{\text {th }}, 12^{\text {th }}, 14^{\text {th }}, 19^{\text {th }}, 33^{\text {rd }}, 37^{\text {th }}, 57^{\text {th }}, 64^{\text {th }}, 66^{\text {th }}$ and $86^{\text {th }}$ costliest regulations in OE's analysis (see Table 2 , column 1 in supplementary materials). Six were occupational health and safety regulations, two related to restrictions on working time, and one each were concerned with equal treatment at work 
TABLE 1. Summary of Selected Cost and Benefit-Related Data from Labour-Related Final Impact Assessments

\begin{tabular}{|c|c|c|c|c|c|c|c|c|}
\hline Regulation & $\begin{array}{l}\text { Reported } \\
\text { cost } \\
\text { in OE’s } \\
\text { analysis } \\
(\mathfrak{E m}, 2014)\end{array}$ & $\begin{array}{l}\text { Reported } \\
\text { benefit in } \\
\text { OE's } \\
\text { analysis } \\
(\mathfrak{E m}, 2014)\end{array}$ & $\begin{array}{l}\text { EANCB } \\
(\mathfrak{E m} \text {, price } \\
\text { base } \\
\text { year 2009) }\end{array}$ & $\begin{array}{l}\text { Reliance on } \\
\text { business } \\
\text { information }\end{array}$ & $\begin{array}{l}\text { Verification of } \\
\text { business } \\
\text { estimates \& } \\
\text { information }\end{array}$ & $\begin{array}{l}\text { Summary of } \\
\text { reported } \\
\text { uncertainties } \\
\text { and assumptions }\end{array}$ & $\begin{array}{l}\text { Summary of } \\
\text { non-reported } \\
\text { benefits }\end{array}$ & $\begin{array}{l}\text { Summary of } \\
\text { non-monetised } \\
\text { benefits }\end{array}$ \\
\hline $\begin{array}{l}\text { The Agency Workers } \\
\text { Regulations } 2010\end{array}$ & 2,210 & 1,574 & $\mathrm{n} / \mathrm{a}$ & Minimal & Not relevant & $\begin{array}{l}\text { Material cost-relevant } \\
\text { assumptions based on } \\
\text { uncertain and absent } \\
\text { evidence/information }\end{array}$ & $\begin{array}{l}\text { Moderate } \\
\text { non-reporting } \\
\text { of benefits to } \\
\text { workers, } \\
\text { employers, and } \\
\text { government }\end{array}$ & $\begin{array}{l}\text { Moderate non- } \\
\text { monetisation } \\
\text { of benefits }\end{array}$ \\
\hline $\begin{array}{c}\text { The Road Transport } \\
\text { (Working Time) } \\
\text { Regulations 2005 }\end{array}$ & 625 & 101 & $\mathrm{n} / \mathrm{a}$ & Moderate & $\begin{array}{l}\text { Some evidence of } \\
\text { verification, } \\
\text { and partial } \\
\text { rejection }\end{array}$ & $\begin{array}{l}\text { Material cost-relevant } \\
\text { assumptions based on } \\
\text { uncertain and absent } \\
\text { evidence/information }\end{array}$ & $\begin{array}{l}\text { Moderate } \\
\text { non-reporting } \\
\text { of benefits to } \\
\text { workers, } \\
\text { employers, and } \\
\text { government. }\end{array}$ & $\begin{array}{l}\text { Significant non- } \\
\text { monetisation } \\
\text { of benefits }\end{array}$ \\
\hline $\begin{array}{l}\text { The Road Transport } \\
\text { (Working Time) } \\
\text { (Amendment) } \\
\text { Regulations 2012) }\end{array}$ & o & & & Minimal & Not relevant & $\begin{array}{l}\text { Material cost-relevant } \\
\text { assumptions based on } \\
\text { uncertain and absent } \\
\text { evidence/ information }\end{array}$ & $\begin{array}{l}\text { Moderate } \\
\text { non-reporting } \\
\text { of benefits to } \\
\text { workers, } \\
\text { employers, and } \\
\text { government. }\end{array}$ & $\begin{array}{l}\text { Significant non- } \\
\text { monetisation } \\
\text { of benefits }\end{array}$ \\
\hline
\end{tabular}


TABLE 1. Continued.

\begin{tabular}{|c|c|c|c|c|c|c|c|c|}
\hline $\begin{array}{l}\text { The Control of } \\
\text { Vibration at Work } \\
\text { Regulations } 2005\end{array}$ & 441 & 263 & $\mathrm{n} / \mathrm{a}$ & Moderate & $\begin{array}{l}\text { No evidence of } \\
\text { verification }\end{array}$ & $\begin{array}{l}\text { Material cost-relevant } \\
\text { assumptions based on } \\
\text { uncertain and absent } \\
\text { evidence/information }\end{array}$ & $\begin{array}{l}\text { Moderate } \\
\text { non-reporting } \\
\text { of benefits to } \\
\text { workers, } \\
\text { employers, and } \\
\text { government }\end{array}$ & $\begin{array}{l}\text { Significant non- } \\
\text { monetisation } \\
\text { of benefits. }\end{array}$ \\
\hline $\begin{array}{l}\text { The Working Time } \\
\text { (Amendment) } \\
\text { Regulations 2002 }\end{array}$ & 308 & 0 & $\mathrm{n} / \mathrm{a}$ & Minimal & Not relevant & $\begin{array}{l}\text { Material cost-relevant } \\
\text { assumptions based on } \\
\text { uncertain and absent } \\
\text { evidence/data }\end{array}$ & $\begin{array}{l}\text { Systematic } \\
\text { reporting of } \\
\text { benefits for } \\
\text { workers; } \\
\text { moderate } \\
\text { non-reporting } \\
\text { of benefits to } \\
\text { employers, and } \\
\text { government. }\end{array}$ & $\begin{array}{l}\text { Comprehensive } \\
\text { non- } \\
\text { monetisation } \\
\text { of benefits }\end{array}$ \\
\hline
\end{tabular}


TABLE 1. Continued.

\begin{tabular}{|c|c|c|c|c|c|c|c|c|}
\hline Regulation & $\begin{array}{l}\text { Reported } \\
\text { cost } \\
\text { in OE’s } \\
\text { analysis } \\
(\mathfrak{E m}, 2014)\end{array}$ & $\begin{array}{l}\text { Reported } \\
\text { benefit in } \\
\text { OE’s } \\
\text { analysis } \\
(\mathfrak{E m}, 2014)\end{array}$ & $\begin{array}{l}\text { EANCB } \\
\text { (£m, price } \\
\text { base } \\
\text { year 2009) }\end{array}$ & $\begin{array}{l}\text { Reliance on } \\
\text { business } \\
\text { information }\end{array}$ & $\begin{array}{l}\text { Verification of } \\
\text { business } \\
\text { estimates \& } \\
\text { information }\end{array}$ & $\begin{array}{l}\text { Summary of } \\
\text { reported } \\
\text { uncertainties } \\
\text { and assumptions }\end{array}$ & $\begin{array}{l}\text { Summary of } \\
\text { non-reported } \\
\text { benefits }\end{array}$ & $\begin{array}{l}\text { Summary of } \\
\text { non-monetised } \\
\text { benefits }\end{array}$ \\
\hline $\begin{array}{c}\text { The Work at Height } \\
\text { Regulations } 2005\end{array}$ & 61 & 64 & $\mathrm{n} / \mathrm{a}$ & Significant & $\begin{array}{c}\text { No evidence of } \\
\text { verification }\end{array}$ & $\begin{array}{l}\text { Material cost-relevant } \\
\text { assumptions based on } \\
\text { uncertain and absent } \\
\text { evidence/data }\end{array}$ & $\begin{array}{l}\text { Systematic } \\
\text { reporting of } \\
\text { benefits for } \\
\text { workers, } \\
\text { moderate } \\
\text { reporting for } \\
\text { employers and } \\
\text { government }\end{array}$ & $\begin{array}{l}\text { Moderate non- } \\
\text { monetisation } \\
\text { of benefits }\end{array}$ \\
\hline $\begin{array}{l}\text { The Control of } \\
\text { Asbestos } \\
\text { Regulations } 2012\end{array}$ & 23 & o & 22 & Significant & $\begin{array}{l}\text { No evidence of } \\
\text { verification, } \\
\text { but partial } \\
\text { rejection }\end{array}$ & $\begin{array}{l}\text { Material cost-relevant } \\
\text { assumptions based on } \\
\text { uncertain and absent } \\
\text { evidence/ data }\end{array}$ & $\begin{array}{l}\text { Moderate } \\
\text { non-reporting } \\
\text { of benefits to } \\
\text { workers, } \\
\text { employers, and } \\
\text { government }\end{array}$ & $\begin{array}{c}\text { Systematic non- } \\
\text { monetisation } \\
\text { of benefits }\end{array}$ \\
\hline
\end{tabular}


TABLE 1. Continued.

\begin{tabular}{|c|c|c|c|c|c|c|c|c|}
\hline Regulation & $\begin{array}{l}\text { Reported } \\
\text { cost } \\
\text { in OE’s } \\
\text { analysis } \\
(\mathfrak{E m}, 2014)\end{array}$ & $\begin{array}{l}\text { Reported } \\
\text { benefit in } \\
\text { OE’s } \\
\text { analysis } \\
(\mathfrak{E m}, 2014)\end{array}$ & $\begin{array}{l}\text { EANCB } \\
(\mathfrak{E m} \text {, price } \\
\text { base } \\
\text { year 2009) }\end{array}$ & $\begin{array}{l}\text { Reliance on } \\
\text { business } \\
\text { information }\end{array}$ & $\begin{array}{l}\text { Verification of } \\
\text { business } \\
\text { estimates \& } \\
\text { information }\end{array}$ & $\begin{array}{l}\text { Summary of } \\
\text { reported } \\
\text { uncertainties } \\
\text { and assumptions }\end{array}$ & $\begin{array}{l}\text { Summary of } \\
\text { non-reported } \\
\text { benefits }\end{array}$ & $\begin{array}{l}\text { Summary of } \\
\text { non-monetised } \\
\text { benefits }\end{array}$ \\
\hline $\begin{array}{l}\text { The Control of } \\
\text { Substances } \\
\text { Hazardous to } \\
\text { Health } \\
\text { (Amendment) } \\
\text { Regulations 2004 }\end{array}$ & 12 & 45 & $\mathrm{n} / \mathrm{a}$ & Moderate & $\begin{array}{l}\text { No evidence of } \\
\text { verification, } \\
\text { but partial } \\
\text { rejection }\end{array}$ & $\begin{array}{l}\text { Limited material } \\
\text { cost-relevant } \\
\text { assumptions based on } \\
\text { uncertain } \\
\text { evidence/data }\end{array}$ & $\begin{array}{l}\text { Systematic } \\
\text { reporting of } \\
\text { benefits for } \\
\text { workers, } \\
\text { moderate } \\
\text { reporting for } \\
\text { employers and } \\
\text { government }\end{array}$ & $\begin{array}{l}\text { Significant non- } \\
\text { monetisation } \\
\text { of benefits }\end{array}$ \\
\hline $\begin{array}{l}\text { Construction } \\
\text { (Design and } \\
\text { Management) } \\
\text { (CDM) } \\
\text { Regulations } 2015\end{array}$ & 10 & 27 & -12.4 & Significant & $\begin{array}{c}\text { No evidence of } \\
\text { verification }\end{array}$ & $\begin{array}{l}\text { Material cost-relevant } \\
\text { assumptions based on } \\
\text { uncertain evidence/ } \\
\text { data }\end{array}$ & $\begin{array}{l}\text { Systematic } \\
\text { reporting of } \\
\text { benefits for } \\
\text { employers and } \\
\text { workers }\end{array}$ & $\begin{array}{l}\text { Systematic } \\
\text { monetisation } \\
\text { of benefits }\end{array}$ \\
\hline $\begin{array}{l}\text { The Transnational } \\
\text { Information and } \\
\text { Consultation of } \\
\text { Employees } \\
\text { (Amendment) } \\
\text { Regulations 2010 }\end{array}$ & 6 & o & $\mathrm{n} / \mathrm{a}$ & Significant & $\begin{array}{c}\text { No evidence of } \\
\text { verification }\end{array}$ & $\begin{array}{l}\text { Material cost-relevant } \\
\text { assumptions based on } \\
\text { uncertain \& } \\
\text { incomplete evidence/ } \\
\text { data }\end{array}$ & $\begin{array}{l}\text { Systematic } \\
\text { reporting of } \\
\text { benefits for } \\
\text { employers and } \\
\text { workers }\end{array}$ & $\begin{array}{l}\text { Comprehensive } \\
\text { non- } \\
\text { monetisation } \\
\text { of benefits }\end{array}$ \\
\hline
\end{tabular}


and worker consultation. In all, 11 impact assessments were reviewed (reflecting the fact that OE combined costs for the 2005 and 2012 Road Transport (Working Time) Regulations) (Table 2 in supplementary materials). Monetised estimated benefits were zero in respect of four. For the remainder, monetised estimated costs were greater than benefits in four, and less in three. The impact assessments were thematically analysed using the techniques of thematic analysis outlined by Guest et al. (Guest et al., 2012): conceptual coding (using Nvivo software), theme development, systematic conceptual comparison, attention to divergent data, and conceptual explanatory conclusions. Coding was inductive and emergent and informed by the literature comparing ex ante estimates in impact assessments with ex post evaluations. ${ }^{2}$ Relevant extracts from the assessments are outlined in Table 3 in the supplementary materials and summarised in Table 1 above.

\section{Business (administrative and policy) costs: nescience and information asymmetries.}

The collective lack of curiosity about the provenance of aggregate estimates of regulatory costs to some extent reflects deeply ingrained cultural assumptions about the needs and interests of business within contemporary market societies. Regulation is now primarily thought of in terms of business costs (Department for Business Innovation and Skills, 2014), rather than something that imparts social benefits, which reflects the efforts of business organisations to link regulatory costs to declining competitiveness and productivity (Select Committee on Economic Affairs, 2004). However, it also reflects the authority that impact assessments now command in public administration. Impact assesssments are essentially evidence-based evaluations of the economic, social, and environmental effects of public policy (Radaelli, 2009). Government departments are required to consider the impact of new or amended policies and regulations to ensure that regulatory costs are kept to a minimum and use impact assessments to both challenge the need for government intervention and to identify the most cost-effective policy and method of implementation. As a result of the establishment of new administrative bodies and procedures, impact assessments can now be used to obstruct the progression of policy proposals through the political process, which reinforces their status as valid and robust statements of the relative costs and benefits of public policy (Lie et al., forthcoming).

OE sought to exploit this status in an earlier iteration of its analysis which it described as 'an attempt to provide hard, quantified evidence' on the effect of regulation on the UK economy (Gaskell and Persson, 2010). However, this claim neglects the fact that estimated costs and benefits in impact assessments are widely recognised as unreliable amongst policy actors. In 2005, the US Office of Management and Budget, which has responsibility for reviewing regulatory proposals by executive agencies, reported that 'an ex ante estimate is no more 
than an informed guess' and, like other forms of prospective modelling, 'may or may not prove to be accurate, once real-world experience with the rule is accumulated and analysed' (Office of Management and Budget, 2005). The unreliability of estimates is to be expected given the inherent uncertainties in predicting future behaviour and anticipating how firms will respond to policies in fast-moving commercial contexts, particularly those characterised by technological change (Harrington et al., 2000). It also reflects difficulties in obtaining reliable data. Many of the estimates in our sample relied heavily on assumptions based on either weak or inconsistent data. Departments encountered considerable difficulties in sourcing precise information covering even the most basic issues, such as the number of businesses or workers likely to be covered by regulations (see generally Table 3, column 2 in supplementary materials). In some cases, assumptions appear to be made with reference to no data at all. In the consultation to The Road Transport (Working Time) Regulations 2005 (Table 2 in supplementary materials), for example, just under half of employers claimed that new vehicles would be required once the regulations took effect. Although the impact assessment noted that this might be 'a little pessimistic', and there was no further evidence of either the number or length of time additional vehicles would be required, it provided an 'illustrative' cost, assuming an extra 12,600 vehicles would be required, each leased for six months at $\mathfrak{E}_{500}$ per month (Table 3 , column 3 in supplementary materials under effect on estimates). In the absence of bias, these uncertainties would have little bearing on the validity of studies which seek to aggregate estimated costs and benefits: overestimates would occur as often as underestimates and effectively cancel one another out. In practice, though, the balance of evidence suggests that estimates exhibit systematic biases overestimating future costs.

Existing studies typically evaluate the accuracy of impact assessment estimates by comparing ex ante estimates in impact assessments with independently conducted ex post assessments. The evidence is relatively limited, differs in approaches taken to estimating costs (Kopits et al., 2014), and may also be explained partly by biases in sampling (Table 1 , Column 4, in supplementary materials). Nonetheless, the findings of these studies (Table 1 , Column 4 in supplementary materials) suggest that ex ante estimates of the costs to business often exceed ex post estimates by a considerable margin, and that this tendency is consistent across policy domains, different types of policy instruments, and jurisdictions. The reasons underlying this phenomenon are likely to vary according to policy area and design (Harrington et al., 2000), and jurisdiction (McGarity and Ruttenberg, 2002). Evaluations of impact assessments of environmental policy, where the phenomenon has been studied in greatest depth, highlight a number of recurring causes such as the failure to anticipate incomplete implementation and compliance (Bailey et al., 2002; IVM and Ecologic, 2005; MacLeod et al., 2006) and differences in (and potentially 
erroneous) assumptions between ex post and ex ante assessments (IVM and Ecologic, 2005; MacLeod et al., 2006). Interestingly, they also neglect or understate the potential for business to innovate, learn and adapt in response to regulation (Hammitt, 2000; Harrington et al., 2000; Heinzerling and Ackerman, 2002; IVM and Ecologic, 2005; MacLeod et al., 2006), despite this being a fairly well-established phenomenon in the economics literature (Ambec et al., 2013; Brännlund and Lundgren, 2009).

Another potential reason, albeit one that is difficult to measure, concerns the existence of information asymmetries between regulated businesses and policy actors (Harrington et al., 2000; MacLeod et al., 2006; Morgenstern et al., 2001). In assessing the potential economic impact of policy decisions, policymakers are often imperfectly informed about the potential economic impacts of policy decisions and are dependent on information from potentially affected businesses, which typically know more about the costs and alternatives for meeting policy decisions (Hammitt, 2000) and represent a low-cost way of obtaining this data (Bernhagen, 2007). In the UK, projected regulatory costs in impact assessments have therefore relied heavily on business estimates (National Audit Office, 2001): a practice indirectly encouraged by official impact assessment guidance (HM Treasury, 2011) and consistent with our sample (Table 1 and Table 3 , column 3 , in supplementary materials). However, relying on business estimates as a measure of actual costs assumes that businesses know the precise impacts of policy proposals. Firms, after all, may only discover cost-saving measures once they are required to comply with regulations (Harrington et al., 2000). It also assumes that businesses can be relied on to provide accurate information on these impacts, despite having a material interest in the outcome of policy proposals and an incentive to provide estimates at the high end of the range (Bernhagen, 2007). The evidence suggests that both assumptions are questionable.

In our sample, businesses were often unable to provide even the most basic information (see, for example, Table 3, columns 2 and 3 in supplementary materials for the Transnational Information and Consultation of Employees (Amendment Regulations) 2010 and The Control of Asbestos Regulations 2012 under material cost-relevant assumptions and summary of business views). Business information and estimates (where reported) also tended to be equivocal or were produced using opaque or questionable methods (see, for example, Table 2, column 3 in supplementary materials for The Road Transport (Working Time) Regulations 2005 and The Control of Substances Hazardous to Health (Amendment) Regulations 2004 under effect on estimates).

In addition, there is now strong evidence suggesting that businesses often act strategically in policy conflicts by overestimating policy-related costs (Bailey et al., 2002; International Chemical Secretariat, 2015; McGarity and Ruttenberg, 2002; Stockholm Environment Institute, 1999). Businesses may, for example, purposefully exaggerate expenditures and only calculate costs for more expensive 
options, whilst trialling less expensive options once the policy has been introduced (Hammitt, 2000). They may also include costs of upgrading additional equipment and processes introduced alongside changes specifically required by regulation (Heinzerling and Ackerman, 2002). Even the most scrupulous businesses are likely to provide estimates in the higher range in order, quite reasonably, to minimise the potentially serious commercial risks of under-costing (Ecotec and GHK Quality Strategy, 2002). There is good evidence to suggest that this phenomenon extends to impact assessments (Hammitt, 2000; MacLeod et al., 2006). Whether it represents a systematic problem in UK impact assessments remains unclear, partly because of the very information asymmetries that make the practice possible (but see The Control of Substances Hazardous to Health (Amendment) Regulations 2004, Table 3, column 2 in supplementary materials, under effect on estimates). Nonetheless, the conditions exist for impact assessments to be unduly influenced by business overestimation of costs. In our sample, business estimates were typically higher than those made by officials. Information originating from business relevant to key assumptions also served to increase estimated costs between pre- and post-consultation impact assessments (Table 3, column 3 , in supplementary materials under effect on estimates). This information was not invariably incorporated into final impact assessment estimates: officials sometimes rejected information or accepted business claims in principle, but adjusted them downwards where other, reliable, evidence suggested this was reasonable (see, for example Table 3 , columns 2 and 3 in supplementary materials for The Road Transport (Working Time) Regulations 2005 under material costrelevant assumptions and effect on estimates). However, it was more common for officials to accept business information at face value (Table 1 and Table 3, column 3 under effect on estimates), which affords little disincentive for overestimation and provides an enabling context for inflated cost estimates in final impact assessments.

There are, as such, uncertainties involved in working out whether, and to what extent, cost estimates are inflated in EU-derived regulation (Simpson, 2014). These uncertainties are compounded by the existence of downward biases in cost estimates. Indirect and difficult-to-measure categories (such as diverted management attention and innovations not made because of the time and resources devoted to complying with regulations), for instance, may be excluded. ${ }^{3}$ In practice, however, these difficult-to-measure items are usually of greater relevance to estimates of indirect business costs rather than administrative and policy costs: the extent to which impact assessments fail to include them, as such, is unlikely to significantly affect OE's cost estimates. The key point, though, is that, on balance, factors producing upward biases appear to be more significant. Impact assessments, it seems, may be a useful tool for encouraging policy actors to think about economic, environmental and social implications of policy proposals but do not necessarily provide 
accurate predictions of actual costs and are not a policy output that can be usefully deployed in claims-making about the costs to business of government policies.

\section{Social, environmental, and business benefits}

Despite highlighting the costs of regulation to business, aggregated analyses which calculate both sides of the cost-benefit equation commonly find that estimated benefits (to business, society and the environment) outweigh costs by some margin. In OE's analysis, total monetised benefits $(\mathfrak{E} 58,579 \mathrm{~m})$ outstripped costs $\left(\mathfrak{E}_{33}, 269 \mathrm{~m}\right)$ by over $\mathfrak{E}_{25}$,00om (2014 prices) (Swidlicki, 2015). This may go some way to explaining why OE has taken great pains to emphasise that estimated benefits of key regulations are 'vastly over-stated' (Swidlicki, 2015) and that 'with more than half of the regulations there [are] no clear benefits' (Anon, 2016). This last observation reflects the fact that, on a case-by-case basis, reported monetised costs for regulations in OE's analysis exceed reported benefits by 57 to 39 (in four cases the reported sums were the same) and that in 26 cases the reported monetised benefits were zero. But to what extent should this method of presenting benefits be accepted at face value?

One important point to make, which is not often apparent when the costs and benefits of regulation are compared, is that devaluing regulatory benefits is easier to achieve where regulation is discussed as an abstraction and benefits are approached purely in economic terms. It is much harder where they are considered with reference to how they improve lives, which can place an entirely different weight on the social value of government action. To take one example, the European Commission has estimated that its Directive on industrial emissions $\left(2010 / 75 / \mathrm{EU}^{4}\right)$, which aims to reduce industrial emissions across the EU (European Union, 2010), will, for large combustion plants alone, lead to an annual reduction of 13,000 premature deaths and 125,000 years of life lost (European Commission, 2016). This does not, however, strictly address OE's objections, which suggest that there are grounds for scepticism of estimated benefits either because they are inadequate relative to the costs they impose, or because they exhibit systematic biases, which overestimate their effects.

One problem with OE's presentation of monetised benefits is that it collapses effects on different social groups. This feeds into, and helps reinforce, the tendency to cast regulation as a struggle for resources between business (whose needs must be prioritised over time in market-based economies - see Farnsworth in this volume), and other, dependent, constituencies, such as workers, the public, and government (whose interests are typically represented as being of secondary importance - see below). However, restricting estimates of business costs to administrative and direct policy costs can represent a misleading way of 
balancing costs and benefits between business and these other groups. In practice, many benefits that accrue to other groups indirectly benefit business, which offset monetised administrative and direct policy costs. Occupational health and safety regulations that reduce worker discomfort, absences, turnover, and early retirement, for example, increase worker and business productivity, and reduce business administrative costs associated with absenteeism, recruitment and retraining (see Table 3, column 4, in supplementary materials under reported and non-reported benefits (employers)). Equally, regulations that encourage technical fixes to social problems may increase the sales of firms supplying these services (see Table 3, column 4 in supplementary materials under non-reported benefits). Even benefits that involve transfer payments from businesses to workers, such as the Agency Workers Regulations 2010 (see Tables 2 and 3, column 4 in supplementary materials), will benefit business in so far as workers spend (or invest) their increased take elsewhere in the economy. Almost all the regulations in our sample provided at least some benefits to business (even though these were not always costed or reported, see Table 3, column 4 in supplementary materials). Over the last six years, impact assessments have specifically sought to capture some of these benefits in the form of the equivalent annual net cost to business (EANCB). The data included in the EANCB is relatively limited, and omits many potential business benefits (HM Government, 2011). Nonetheless, EANCB calculations can recast the magnitude of business costs quite significantly. For example, the EANCB for The Construction (Design and Management) Regulations 2015 suggests a net gain to business of $\mathfrak{E}_{12.4}$ million, but in OE's analysis it represents an annual cost to business of $\mathfrak{E}_{10}$ million (Table 1 ).

On the issue of whether there are systematic biases in estimated benefits the evidence is not entirely consistent. There is some evidence from the US to suggest that impact assessments may inflate estimated benefits, because of their tendency to (erroneously) assume full compliance with regulations (Harrington et al., 200o). In our sample, officials' approach to estimating compliance was mixed (see Table 3, column 2 in supplementary material under assumptions relevant to the rate of compliance). More to the point though, benefits to workers, business, and government were routinely overlooked (Table 1 and Table 3, column 4 in supplementary materials under non-reported benefits). This is consistent with other evidence, which suggests that UK policy actors place far less emphasis on ensuring that social and environmental benefits are rigorously mapped in impact assessments than they do on business costs. A recent study commissioned by the Department of Environment and Rural Affairs (DEFRA) of impact assessments produced by government departments between 2008 and 2011, for example, found that while over 8 o per cent treated economic impacts with medium or high rigour, social impacts were treated with low rigour or not at all in 52 per cent of cases (the corresponding figure for environmental impacts was 50 per cent) (Tinch et al., 2014). 
UK policymakers' apparent relative lack of attention to benefits compounds technical problems in monetising benefits. Benefits are often complex and multicausal (see, for example, Table 3, column 4 in supplementary materials for The Road Transport (Working Time) (Amendment) Regulations 2012 under disputed benefits), difficult to measure (see, for example, Table 3, column 4 in supplementary materials for The Transnational Information and Consultation of Employees (Amendment) Regulations 2010 under non-monetised benefits (workers and employers)), long-term and not priced in the market. This problematises their monetisation (Smith et al., 2010) and may also lead to them being out of scope of impact assessments where the typical appraisal period is 10 years. The potential effect of this last point on OE's calculation of benefits is illustrated by its treatment of benefits associated with The Control of Noise at Work Regulations 2005 (Table 2 in supplementary materials). OE used figures presented in the impact assessment for 10 years. However, the impact of noise on hearing is cumulative and there is a long latency before the effects become manifest. These factors were reflected in large differences in the estimated health benefits quantified over ten years (range $\mathfrak{E}_{72.1 \mathrm{~m}}$ and $\mathfrak{E}_{72} .3 \mathrm{~m}$ in present, 2005, net value terms) and forty years (range $\mathfrak{E} 1.31 \mathrm{bn}$ and $\mathfrak{E} 1.39 \mathrm{bn}$, in present, 2005, net value terms), which were also outlined in the impact assessment. By basing its calculations on the 10-year estimate, OE reported an annual benefit of $\mathfrak{E} 10 \mathrm{~m}$ (2014 prices), significantly lower than the $\mathfrak{E} 45 \mathrm{~m}$ (2014 prices) annual benefit that it would have reported if it had used the 40-year projections as the base for its estimate (Health and Safety Executive, 2005).

Problems of quantification are exacerbated by a dearth of impact assessmentready evidence. This partly reflects the political economy of research on issues relating to regulation. Historically, for instance, the literature on the economic impacts of occupational health and safety regulations has focused on compliance costs for business, rather than other groups (such as workers and their families, government, and the general public), and has neglected cumulative economic impacts (such as the effects of work-related accidents and ill health on lost output - see, for example, The Control of Vibration at Work Regulations 2005, Table 3, column 4 in supplementary materials under non-monetised benefits) (Centre for Strategy and Evaluation Services, 2009). Data concerning the impact of working conditions on occupational health are also widely understood to under-report the effects of corporate activity on human health and welfare, which limits the measurable, and, therefore, monetisable pool of potential benefits a proposed regulation can deliver (see, for example, Table 3, column 4 for The Control of Substances Hazardous to Health (Amendment) Regulations 2004 under non-monetised benefits (workers) and column 2 for The Control of Vibration at Work Regulations 2005 under material cost-relevant assumptions and non-monetised benefits (general)). These problems are compounded by the fact that businesses are potentially an even poorer source of evidence of economic 
benefits than they are for costs. For example, many do not know how much accidents or work-related illness cost their businesses; a function of limited time and resources, perceived complexity and an absence of expertise (Haefeli et al., 2005). In fact, our sample suggests that this phenomenon cuts across different types of benefits (see generally Table 3, columns 2, 3 and 4 in supplementary materials) and that, in practice, businesses are just as likely to contest claimed benefits (see, for example, Table 3, column 4 in supplementary materials for The Road Transport (Working Time) (Amendment) Regulations 2012), than provide detailed, quantifiable, evidence necessary for their monetisation. The result is that benefits are rarely fully monetised. The aforementioned DEFRA study found full quantification and monetary valuation to be a relatively rare occurrence. Assessments in two-thirds of impact assessments identifying environmental impacts, and three-quarters identifying social impacts, were primarily descriptive. Only one in eight systematically quantified environmental impacts (Tinch et al., 2014). This is consistent with our sample: systematic monetisation was rare ( 1 in 11 ) and, where monetised benefits were reported as zero, this was primarily due to methodological difficulties attendant on monetisation, rather than because the regulations concerned were unlikely to produce any benefits (Table 1 and Table 3, column 4 in supplementary materials).

Finally, in contrast to costs which can be valued with reference to market prices, some values, such as social justice, are incapable of measurement, let alone monetisation (Torriti, 2011). This highlights a more profound problem concerning the political and disciplinary assumptions that are built into valuing benefits which can produce some perverse results. Using quality-adjusted life years (QALYs), for example, devalues the lives of elderly people (who have fewer QALYs to live) and disabled people (who have reduced QALYs) (Smith et al., 2010). Thus, even where the evidence is strong, and methods rigorously applied, it does not necessarily follow that the final figures fully reflect benefits as understood by non-economists.

\section{The cost-competitiveness-employment conundrum}

The relatively well-established doubts concerning the validity of costs and benefits in impact assessments are arguably sufficient in themselves to dismiss aggregated monetised analyses as useful epistemological tools for understanding the impact of EU-derived regulation on the UK economy and society. Nonetheless, their political appeal remains relatively undimmed. Outwardly, this attraction rests on a virtuous premise: that, over time, regulation decreases employment as a result of the permanent pressure it places on business competitiveness and output (Ambler et al., 2010; Congdon, 2014). As Ambler et al. put it, 'Transferring money from wealth creating business to wealth consuming citizens will, sooner 
or later, damage competitiveness and reduce employment' (Ambler et al., 2010). The proposed causal mechanisms here are complex and overlapping. Among other things, regulation is said to raise firm costs, which raises the costs of product and services, which in turn leads to a reduction in sales and, inevitably, in employment. Regulation is also said to divert firm resources away from savings, investment and capital formation, which reduces innovation and development of new technologies, processes, products, and services that may increase productivity, lower prices and increase sales. In addition, some authors have pointed to the uncertainties regulation creates, which is said to have a depressive effect on new hiring and investment (Coglianese and Carrigan, 2013; Shapiro and Irons, 2011). These effects can, and do, occur. However, there are several problems in applying this thinking to regulation as an undifferentiated phenomenon. One obvious point is that increased costs do not inevitably decrease competitiveness. Competitiveness is a relational concept, which involves the ability of a firm to provide products or services (of comparable quality) more effectively and efficiently (and at lower costs) than other firms. Estimating the impact of regulatory costs on competitiveness therefore requires a distinction to be made between traded industries, where firms in a specific sector sell or are capable of selling a significant share of their output outside of the regulated geographical region (the $\mathrm{UK}$ and $\mathrm{EU}$ in this case), and non-traded industries. Where regulation applies to non-traded industries, its effect on aggregate firm competitiveness and, therefore, employment is likely to be less significant. This is not to say that regulation will have no effect on affected firms in non-traded industries. Businesses that can more readily absorb costs without raising prices in the short term (because, for example, they have superior access to capital and can offset investments by greater economies of scale) will, over time, do better relative to their competitors. Regulation may also have an effect on inflation by raising prices in non-traded industries. However, whether these effects occur and what effect they have on employment are, ultimately, empirical questions which turn on the precise form of the regulation, the sector it affects, and how regulated firms respond to their altered regulatory environment (Frontier Economics, 2012).

A similar point can be made about the effects of regulation on employment in traded industries. Environmental regulation, for example, can increase employment in pollution abatement, which offsets jobs losses that may occur as a result of administrative and policy costs. Regulation can also improve worker and public health, leading to lower health care costs and increased worker productivity. It can also increase innovation and, under certain conditions, lead to improved firm performance: both of which may have a positive impact on employment (Coglianese et al., 2013). In short, effects of regulation on employment are highly contextualised and evaluating the impact of regulatory costs on both firm and economy-wide competitiveness and employment can 
only be meaningfully analysed with reference to specific regulations in specific circumstances. In fact, one well-received review of studies on the impact of regulation on employment in the US has found that the net effects have been close to zero (Coglianese et al., 2013).

\section{Discussion}

Aggregate calculations of the cost of EU-derived regulation play an important role in lending weight to claims of the negative impact of regulation on business competitiveness and employment in the UK. However, their methodological weaknesses suggest that their key significance may reside less in what they can tell us about the relationship between regulation, business performance, and public welfare, and more in what they suggest about the interdependencies between the economisation of public policy, the fungibility of impact assessment data, and the political market for contemporary policy-relevant knowledge.

Impact assessments represent a key component of government efforts to embed economic rationality into everyday routines of policymaking (Morgan, 2003). They seek to standardise how government intervention in the economy should be perceived and evaluated and have become an authoritative basis for the deliberation of policy: partly because they represent a genuine attempt to systematise the evaluation of projected effects and place an emphasis on numerical values, which implies precision, but also because of how they are governed. Impact assessment methodologies rest on the disciplinary practices of microeconomics and are policed by new administrative institutions, such as the Regulatory Policy Committee, which determine which data government departments should collate, from whom, and how they should be interpreted (Lie et al., forthcoming). This framework has progressively reinforced their status as trusted measures of policy effects but, at the same time, provides a basis for their misappropriation by rendering their assumptions, biases, and uncertainties relatively inaccessible to independent scrutiny. Opacity to summary analysis, in conjunction with the availability of multiple (and incomplete) numerical values creates a fungible (and flexible) pool of data for policy reappraisal, which afford various representations of policy proposals that can be spliced and interpreted in different ways to suit the political programmes of different constituencies. In this respect as such, aggregate analyses are as much a measure of desired direction of political travel, as a statement of the problems of the British economy.

In the present case, this observation derives support from two other issues that $\mathrm{OE}$ failed to consider, which are fundamental to accurately estimating the proportion of regulatory costs that should be attributed to EU membership (Springford, 2016). First, some EU regulations originate from international commitments and obligations, which OE costed into its analysis even though the UK may have implemented similar measures if it had not been a member of the 
EU (PWC, 2016). Second, the UK has gone beyond the minimum requirements demanded by the EU in respect of several EU Directives in OE's analysis (PWC, 2016; Sack, 2013), including the Working Time Directive (2003/88/EC), Part Time Work Directive (1997/81/EC, 1998/23/EC) and Parental Leave Directive (2010/18/EC). Interestingly, OE had previously raised the issue of gold-plating in evidence to the Department for Business, Innovation and Skills' review of the balance of competencies between the UK and EU on social and employment policy (HM Government, 2014), but neglected to adjust for this in its analysis despite the fact that costs resulting from over-compliance do not directly result from EU law-making.

It is easy to dismiss the multiple weaknesses of OE's analysis as largely irrelevant to the big issues facing the UK economy as the country prepares to leave the EU. But aggregate cost analyses compete for political space with other ideas for boosting productivity and competitiveness which are likely to have a more benign effect on social inequalities and environmental protection, such as addressing skills shortages, underinvestment in research and development, overinvestment in property, and public investment in green technologies. They also help to drown out the implications of other sources of data, which provide the basis for alternative accounts of how deregulation may affect competitiveness. European regulation has not prevented the UK from having one of the most lightly regulated economies amongst countries in the Organisation of Economic Co-operation and Development (OECD). The best available measures suggest that it has the second least regulated product markets in the OECD, and employment protection legislation that is only marginally more restrictive than the US or Canada, less so than Australia, and far lower than other European countries in the OECD (Koske et al., 2015; Organisation of Economic Co-operation and Development, 2014). Despite this, the political constituency that formed around the Leave Campaign has continued to extol the economic advantages of the regulatory flexibility offered by the referendum result and has advocated that the government individually review all EU-derived legal instruments so that key environmental and social regulations (such as those associated with the Working Time and Agency Workers Directives and Regulation on the Registration, Evaluation, Authorisation and Restriction on Chemicals (Buckle et al., 2015) can be repealed or radically scaled back.

This conviction in competitive deregulation as the most potent means of securing future British economic and social prosperity is difficult to fathom given the evidence outlined above, the UK's scope for deregulation, its extant international commitments, the needs of its largest companies to maintain access to the EU, or econometric analyses, which generally associate the UK's membership of the single market with higher growth, increased foreign direct investment, and higher average incomes (Campos et al., 2014; Bruno et al., 2016). These factors help to explain the more pragmatic position taken by the 
Confederation of British Industry (CBI), the UK's most influential business association, which has consistently stressed that the advantages of access provided by regulatory equivalence outweigh the costs (Confederation of British Industry, 2016c). Its preferred option involves continued regulatory equivalence in the short and medium term; a recognition that any competitive advantages from weaker regulation will potentially be offset by restrictions in market access, increased costs for firms exporting to the EU, and reduced growth. However, whether this represents a distinct agenda or simply a difference in priorities and emphasis, moderated by the specific interests of its membership, ${ }^{5}$ is a moot point. The CBI's position is underpinned by a desire for stability. Over the longer term, it recognises the value of regulatory divergence where this is consistent with optimum access to EU markets and continued inward investment (Confederation of British Industry, 2016a, 2016c). To this end, it has advocated deregulation in areas of EU regulation that the UK has over-implemented (and so can be streamlined without harming preferential trading with the EU) and highlighted the importance of the UK resisting implementation of further social and employment regulation (Confederation of British Industry, 2016c), which reflects its past opposition to the Temporary Agency Workers Directive and Working Time Directive (Confederation of British Industry, 2015).

These commonalities point to deeper drivers of domestic regulatory policy, which help to explain the sometimes uncompromising and under-analysed claims about EU-derived regulation. At their heart, regulatory debates are discussions about who should bear the costs and reap the benefits of economic activity. Many regulations have a redistributive effect, transferring resources from businesses to workers, the public, government, and future generations. Deeply held philosophical assumptions about the rights of capital, the appropriate role of the state in market economies, and the primacy of capital accumulation, as much as evidence, seems to be driving regulatory policy: a political-moral opposition to public intervention in markets and scepticism of the social value of redistributive politics. The key objection, as Ambler et al. have put it, may simply be that 'politicians have grabbed regulation as a "free" way to increase social benefits without the transparency of taxation' (Ambler et al., 2010).

\section{Supplementary material}

To view supplementary material for this article, please visit https://doi. org/10.1017/So047279417000526

\section{Notes}

1 Where open-ended questions are asked in the absence of cues, for example, regulation often ranks low down the list of self-reported problems (Allinson et al., 2006; Baldock and Blundel, 2014).

2 Detailed coding descriptions available on request from authors. 
3 For contrasting examples see the impact assessment for Control of Asbestos Regulations 2012 which did not account for opportunity costs and the impact assessment and associated material for the Transnational Information and Consultation of Employees (Amendment) Regulations 2010 and Work at Height Regulations 2005 where opportunity costs were included (Tables 2 and 3 in supplementary materials).

4 The $22^{\text {nd }}$ most beneficial and $29^{\text {th }}$ costliest EU-derived regulation in OE's analysis.

5 The CBI's membership was largely behind continued membership of the EU. This reflects three factors: the largely positive (or neutral) effect of EU-derived regulation on earnings; the fact that EU-derived regulations largely represent sunk costs for key sectors (Confederation of British Industry, 2016c); that large firms, in particular, benefit from access to the single market by virtue of their capacity to exploit economies of scale.

6 See Table 3, column 4 in supplementary materials under disputed benefits.

\section{References}

Allinson, G., Houston, M., Braidford, P. and Stone, I. (2006), Myths surrounding growing a business: a focus group based study on behalf of the Small Business Service, London: DTI. http://dro.dur.ac.uk/15043/1/15043.pdf?DDD2+dbrigfa, accessed March 30, 2017.

Ambec, S., Cohen, M.A., Elgie, S. and Lanoie, P. (2013), 'The Porter Hypothesis at 20: Can Environmental Regulation Enhance Innovation and Competitiveness?', Review of Environmental Economics and Policy, 7: 1, 2-22.

Ambler, T., Chittenden, F. and Miccini, A. (2010), Is Regulation Really Good for Us?, London: British Chambers of Commerce. http://www.britishchambers.org.uk/ assets/downloads/policy_reports_2010/is_regulation_really_good_good_for_us.pdf, accessed November 14, 2016.

Anon (2016), Reality Check: What is the cost of EU regulations?, London: BBC.

Anon (undated), Literature review - economic costs and benefits of EU membership (government document released under Freedom of Information Act). https://www.gov.uk/ government/uploads/system/uploads/attachment_data/file/220969/foi_eumembership_ literaturereview.pdf, accessed November 20, 2016.

Ayres, J.G., Boyd, R., Cowie, H. and Hurley, J.F. (2011), 'Costs of occupational asthma in the UK', Thorax, 66: 2, 128-133.

Bailey, P.D., Haq, G. and Gouldson, A. (2002), 'Mind the gap! Comparing ex ante and ex post assessments of the costs of complying with environmental regulation', European Environment, 12: 5, 245-256.

Baldock, R. and Blundel, R. (2014), Quarterly Survey of Small Business in Britain. 3oth Anniversary Issue: celebrating three decades of small firms' research and engagement, Milton Keynes: The Open University Business School. http://www.open.ac.uk/businessschool/sites/www.open.ac.uk.business-school/files/files/publications/download/QS\% 202014\%20Q4\%2030th\%20Anniversary\%2oreport\%20-\%20FINAL.pdf, accessed March 30, 2017.

Bernhagen, P. (2007), The Political Power of Business: Structure and Information in Public PolicyMaking, Abingdon, Oxon: Routledge.

Brännlund, R. and Lundgren, T. (2009), 'Environmental Policy Without Costs? A Review of the Porter Hypothesis', International Review of Environmental and Resource Economics, 3: 2, 75-117.

Breyer, S. (1998), 'Typical Justifications for Regulation', in R. Baldwin, C. Scott and C. Hood (eds.), A Reader on Regulation, Oxford: Oxford University Press.

Bruno, R., Campos, N., Estrin, S. and Tian, M. (2016), Foreign Direct Investment and the Relationship Between the United Kingdom and the European Union. CEP Discussion Paper, No. 1543. London: London School of Economics. http://cep.lse.ac.uk/pubs/download/dp1453.pdf, accessed January 20, 2017. 
Buckle, R., Hewish, T., Hulsman, J.C., Mansfield, I. and Oulds, R. (2015), BREXIT: Directions for Britain Outside the EU. London: Institute of Economic Affairs. https://iea.org.uk/wp-content/uploads/2016/o7/Brexit-interactive.pdf, accessed December 15, 2016.

Campos, N., Coricelli, F. and Moretti, L. (2014), Economic Growth and Political Integration: Estimating the Benefits from Membership of the European Union using the Synthetic Counterfactuals Method. IZA Discussion Paper, No. 8162. Bonn: Institute for the Study of Labor. http://anon-ftp.iza.org/dp8162.pdf, accessed December 15, 2016.

Cash, B. and Jamieson, B. (2004), The Strangulation of Britain and British Business. http://www.europeanfoundation.org/wp-content/uploads/2014/05/The-Strangulationof-Britain-British-Business.pdf, accessed December 5, 2016.

Centre for Strategy and Evaluation Services (2009), Assessing the cumulative economic impacts of health and safety regulations, Sudbury: Health and Safety Executive. http://www.hse.gov.uk/research/rrpdf/rr692.pdf, accessed December 2, 2016.

Coglianese, C. and Carrigan, C. (2013), 'The Jobs and Regulation Debate', in C. Coglianese, A. M. Finkel and C. Carrigan (eds.), Does Regulation Kill Jobs, Philadelphia, Pennsylvania: University of Pennsylvania Press.

Coglianese, C., Finkel, A.M. and Carrigan, C. (2013), Does Regulation Kill Jobs?, Philadelphia, Pennsylvania: University of Pennsylvania Press.

Confederation of British Industry (2015), Our Global Future. The Business Vision for a Reformed EU, London: Confederation of British Industry. http://www.cbi.org.uk/cbiprod/assets/File/pdf/our_global_future.pdf, accessed November 4, 2016.

Confederation of British Industry (2016a), Delivering for Prosperity. A New Agenda for Business and Government, London: Confederation of British Industry. http://www.cbi. org.uk/index.cfm/_api/render/file/?method=inline\&fileID=8D5CA64D-

E5E2-4B2C-ACCDC7DD202A8688, accessed January 1, 2017.

Confederation of British Industry (2016b), CBI Literature review of the impact of EU membership on the UK economy. http://www.cbi.org.uk/business-issues/uk-and-the-europeanunion/eu-business-facts/cbi-literature-review-of-the-impact-of-eu-membership-onthe-uk-economy-pdf/, accessed November 16, 2016.

Confederation of British Industry (2016c), Making a Success of Brexit, London: Confederation of British Industry. http://www.cbi.org.uk/news/making-a-success-of-brexit/, accessed January 1, 2017.

Congdon, T. (2014), How much does the European Union cost Britain? http://www. nesukip.org.uk/wp-content/uploads/Cost_of_the_EU_2015_V_4_1_12_15.pdf, accessed November 3, 2016.

Congdon, T. (2016), 'Too Much Regulation', in R. Bootle (ed.), The Economy after Brexit, London: Economists for Bexit.

Cummings, D. (2016), Oral Evidence: The economic and financial costs and benefits of UK membership of the EU, Treasury Committee, London: House of Commons.

Department for Business Innovation and Skills (2014), Hancock: red tape drive saves business a record $\mathfrak{E}_{10}$ billion, London: Department of Business Innovation and Skills.

Economic Competitiveness Policy Group (2007), Freeing Britain to Compete: Equipping the UK for Globalisation, London. http://johnredwood.wpengine.netdna-cdn. com/wp-content/uploads/2016/o3/ECPGcomplete1-1.pdf, accessed November 20, 2016.

Ecotec and GHK Quality Strategy (2002), A Study to Evaluate Cost Estimates of Specific Measures Associated with the National Air, London: DEFRA. accessed.

European Commission (2016), The IPPC Directive, Brussels: European Commission.

European Union (2010), Directive 2010/75/EU of the European Parliament and of the Council of 24 November 2010 on industrial emissions (integrated pollution prevention and control) (Recast), Brussels: European Union. http://eur-lex.europa.eu/legal-content/ EN/TXT/PDF/?uri=CELEX:32010Lo075\&from=EN, accessed January 24, 2017. 
Federation of Small Businesses (2011), The Burden of Regulation London: Federation of Small Businesses. http://www.fsb.org.uk/LegacySitePath/frontpage/assets/ the\%2oburden\%20of\%2oregulation\%20-\%20may\%202011.pdf, accessed March 30, 2017.

Federation of Small Businesses (2013), FSB response to the Prime Minister's Business Taskforce on EU Regulation, London: Federation of Small Businesses. http://www.fsb.org.uk/ LegacySitePath/policy/assets/fsb\%2oresponse\%20to\%20eu\%2obusiness\%2otaskforce. pdf, accessed April 14, 2017.

Frontier Economics (2012), The impact of regulation on growth. A Report Prepared for the Department of Business, Innovation and Skills, London: Frontier Economics. https:/www.gov.uk/government/uploads/system/uploads/attachment_data/file/32107/ 12-821-impact-of-regulation-on-growth.pdf, accessed.

Gaskell, S. and Persson, M. (2010), Still out of Control? Measuring eleven years of EU regulation, London: Open Europe. http://2ihmoy1d3v7630argh2rsglp.wpengine. netdna-cdn.com/wp-content/uploads/2014/12/2010-06-01-Open_Europe_Report_ still_out_of_control.pdf, accessed November 14, 2016.

Guest, G., MacQueen, K.M. and Namey, E.E. (2012), Applied thematic analysis, London: Sage.

Haefeli, K., Haslam, C. and Haslam, R. (2005), Perceptions of the cost implications of health and safety failures, Sudbury: Health and Safety Executive. http://www.hse.gov.uk/research/rrpdf/rr403.pdf, accessed December 2, 2016.

Hammitt, J.K. (2000), 'Title Are The Costs of Proposed Environmental Regulations Overestimated? Evidence from the CFC Phaseout', Reference Environmental and Resource Economics 16: 3, 218-301.

Harrington, W., Morgenstern, R.D. and Nelson, P. (2000), 'On the accuracy of regulatory cost estimates', Journal of Policy Analysis and Management, 19: 2, 297-322.

Health and Safety Executive (2005), Final Regulatory Impact Assessment of the Control of Noise at Work Regulations 2005, London: Health and Safety Executive. accessed.

Heath, A. (2016), EU red tape is suffocating UK economy and Brexit can set us free, The Telegraph, London.

Heinzerling, L. and Ackerman, F. (2002), 'The Humbugs of the Anti-Regulatory Movement.', Cornell Law Review, 87: 2, 648-670.

HM Government (2011), One-In, One-Out (OIOO) Methodology, London: Department for Business, Innovation and Skills. http://www.regulation.org.uk/ library/2011_oioo_methodology.pdf, accessed June 6, 2014.

HM Government (2013), Review of the Balance of Competences between the United Kingdom and the European Union The Single Market London: HM Government. https://www.gov.uk/government/uploads/system/uploads/attachment_data/file/227069/ 2901084_SingleMarket_acc.pdf, accessed December 6, 2016.

HM Government (2014), Review of the Balance of Competences between the United Kingdom and European Union. Social and Employment Policy, London: HM Government. https://www.gov.uk/government/uploads/system/uploads/attachment_data/file/332524/ review-of-the-balance-of-competences-between-the-united-kingdom-and-theeuropean-union-social-and-employment-policy.pdf, accessed Deecember 9, 2016.

HM Government (2016), HM Treasury analysis: the long-term economic impact of EU membership and the alternatives, London: HM Treasury. https://www.gov. uk/government/uploads/system/uploads/attachment_data/file/517415/treasury_analysis_ economic_impact_of_eu_membership_web.pdf, accessed December 6, 2016.

HM Treasury (2011), The Green Book. Appraisal and Evaluation in Central Government, London: The Stationery Office.

Holehouse, M. (2015), Only way to cut $\mathfrak{E}_{33}$ bn cost of EU is to stay and renegotiate, says report, The Telegraph.

House of Commons Treasury Committee (2016), The economic and financial costs and benefits of the UK's EU membership, London: House of Commons.

International Chemical Secretariat (2015), Cry wolf-predicted costs by industry in the face of new regulations: International Chemical Secretariat. accessed. 
IVM and Ecologic (2005), Literature review on ex-post assessment of costs to business of environmental policies and legislation, Amsterdam: Vrije Universiteit. accessed.

Kitching, J. (2006), 'A Burden on Business? Reviewing the Evidence Base on Regulation and Small-Business Performance', Environment and Planning C: Government and Policy, 24: 6, 799-814.

Kitching, J., Hart, M. and Wilson, N. (2015), 'Burden or benefit? Regulation as a dynamic influence on small business performance', International Small Business Journal, 33: 2, 130-147.

Kopits, E., McGartland, A., Morgan, C., Pasurka, C., Shadbegian, R., Simon, N.B., Simpson, D. and Wolverton, A. (2014), Retrospective cost analyses of EPA regulations: a case study approach. Journal of Benefit-Cost Analysis, 5: 2, 173-193.

Koske, I., Wanner, I., Bitetti, R. and Barbiero, O. (2015), The 2013 update of the OECD's database on product market regulation: Policy insights for OECD and non-OECD countries, Paris: Organisation of Economic Co-Operation and Development. http://www.keepeek.com/Digital-Asset-Management/oecd/economics/the-2013-updateof-the-oecd-s-database-on-product-market-regulation_5js3f5d3n2vl-en\#page16, accessed December 10, 2016.

Lancaster, R., Ward, R., Talbot, P. and Brazier, A. (2003), Costs of Compliance with Health and Safety Regulations in SMEs, Norwich: Health and Safety Executive. http://www.hse.gov.uk/research/rrpdf/rr174.pdf, accessed April 4, 2017.

Lie, J., Fooks, G., Vries, N.K.d., Heijndijk, S.M. and Willemsen, M.C. (forthcoming), 'Can't see the woods for the trees: exploring the range and connection of tobacco industry argumentation in the 2012 UK standardised packaging consultation', Tobacco Control.

MacLeod, M., Morana, D., Harrington, W., Arestia, M.L. and Morgenstern, R.D. (2006), Improving the Accuracy of UK Regulatory Cost Estimates, Edinburgh. http:// regulatoryreform.com/wp-content/uploads/2015/02/UK-Improving-the-Accuracyof-UK-Regulatory-Cost-Estimates.pdf, accessed November 19, 2016.

McGarity, T. and Ruttenberg, R. (2002), 'Counting the Cost of Health, Safety and Environmental Regulation', Texas Law Review, 80: 7, 1997-2058.

Miller, V. (2010), How much legislation comes from Europe?, London: House of Commons. http://researchbriefings.files.parliament.uk/documents/RP10-62/RP10-62.pdf, accessed November 21, 2016.

Miller, V. (2015), EU Obligaions: UK implementing legislation since 1993, London: House of Commons. http://researchbriefings.files.parliament.uk/documents/SNo7092/SN07092.pdf, accessed November 21, 2016.

Milne, I. (2004), A Cost Too Far?, London: Civitas. http://www.civitas.org.uk/pdf/cs37.pdf, accessed November 20, 2016.

Minford, P., Mahambare, V. and Nowell, E. (2005), Should Britain Leave the EU? An Economic Analysis of a Troubled Relationship, Cheltenham: Edward Elgar.

Morgan, B. (2003), 'The Economization of Politics: Meta-Regulation as a Form of Nonjudicial Legality', Social \& Legal Studies, 12: 4, 489-523.

Morgenstern, R., Pizer, W. and Shih, J.-S. (2001), 'The Cost Of Environmental Protection', The Review of Economics and Statistics, 83: 4, 732-738.

National Audit Office (2001), Better Regulation: Making Good Use of Regulatory Impact Assessments, London: National Audit Office. https://www.nao.org.uk/wp-content/ uploads/2001/11/0102329.pdf, accessed November 18, 2016.

National Audit Office and Department for Business Innovation and Skills (2014), Business Perceptions Survey 2014, London: Department for Business Innovation and Skills. https://www.nao.org.uk/wp-content/uploads/2014/05/Business-perceptions-survey2014.pdf, accessed March 20, 2017.

Office of Management and Budget (2005), Validating Regulatory Analysis: Report to Congress on the Costs and Benefits of Federal Regulations and Unfunded Mandates on State, Local, and Tribal Entities, Washington, DC: Office of Information and Regulatory Affairs. 
https://www.whitehouse.gov/sites/default/files/omb/inforeg/2005_cb/final_2005_cb_ report.pdf, accessed November 12, 2016.

Organisation of Economic Co-Operation and Development (2014), OECD Indicators of Employment Protection, Paris: OECD.

Persson, M., Booth, S. and Gaskell, S. (2009), Out of Control? Measuring a decade of EU regulation, London: Open Europe. http://archive.openeurope.org.uk/Content/ documents/Pdfs/outofcontrol.pdf, accessed August 30, 2016.

PWC (2016), HM Government Leaving the EU: Implications for the UK economy, London: PricewaterhouseCoopers. https://www.pwc.co.uk/economic-services/assets/ leaving-the-eu-implications-for-the-uk-economy.pdf, accessed December 5, 2016.

Radaelli, C.M. (2009), 'Measuring policy learning: regulatory impact assessment in Europe', Journal of European Public Policy, 16: 8, 1145-1164.

Sack, P. (2013), The Midas touch: Gold-plating of EU employment directives in UK law, London: Institute of Directors. https://www.iod.com/Portals/o/Badges/PDF's/News\% 2oand\%20Campaigns/Regulation\%20and\%2oemployment/The\%2oMidas\%2otouch\% 2oGold-plating\%20of\%2oEU\%2oemployment\%2odirectives\%2oin\%2oUK\%2olaw.pdf? ver =2016-04-14-101413-697, accessed January 20, 2017.

Select Committee on Economic Affairs (2004), Monetary and Fiscal Policy: Present Successes and Future Problems, Select Committee on Economic Affairs, London: The Stationary Office.

Shapiro, I. and Irons, J. (2011), Regulation, Employment, and the Economy, Washington, D.C.: Economic Policy Institute. http://www.epi.org/files/2011/BriefingPaper305.pdf, accessed January 20, 2017.

Simpson, R. D. (2014), Do regulators overestimate the costs of regulation? Journal of Benefit-Cost Analysis, 5: 2, 315-332.

Smith, K., Fooks, G., Collin, J., Weishaar, H. and Gilmore, A. (2010), 'Is the increasing policy use of Impact Assessment in Europe likely to undermine efforts to achieve healthy public policy?', Journal of Epidemiology and Community Health, 64: 6, 478-487.

Smith, K., Fooks, G., Gilmore, A., Collin, J. and Weishaar, H. (2014), 'Promoting 'Better Regulation': Corporate coalitions and policymaking in the EU', Journal of Health Politics, Policy and Law.

Springford (2016), Brexit and EU regulation: A bonfire of the vanities? http://www. cer.org.uk/sites/default/files/pb_js_regulation_3feb16.pdf, accessed November 3, 2016.

Stockholm Environment Institute (1999), Costs and Strategies presented by Industry during the Negotiation of Environmental Regulations, Stockholm. accessed.

Swidlicki, P. (2015), Top 100 EU rules cost Britain £33.3bn, London: Open Europe. http://openeurope.org.uk/intelligence/britain-and-the-eu/top-10o-eu-rules-cost-britain33-3bn/, accessed November 11, 2016.

Tinch, R., Cryle, P., Mathieu, L., Rudd, T., Fredenham, E., Corbelli, D. and Newhill, L. (2014), Baseline Evaluation of Environmental Appraisal and Sustainable Development Guidance across Government. Final Report for Defra, London: EFTEC. http://randd.defra.gov.uk/Document.aspx?Document=11937_131003_ERG1222_ Appraisals_Final_2014_03_07.pdf, accessed November 19.

Torriti, J. (2011), 'The unsustainable rationality of Impact Assessment', European Journal of Law and Economics, 31: 3, 307-320.

Treasury Committee (2016), The economic and financial costs and benefits of the UK's EU membership, Treasury Committee, London: House of Commons.

Watkiss, P., Baggot, S., Bush, T., Cross, S., Goodwin, J., Holland, M., Hurley, F., Hunt, A., Jones, G., Kollamthodi, S., Murrells, T., Stedman, J. and Vincent, K. (2004), An Evaluation of the Air Quality Strategy: Final Report to Defra, Norwich: AEA Technology. https://uk-air.defra.gov.uk/assets/documents/reports/catog/1403040925_exec-summary. pdf, accessed November 20, 2015. 